\title{
Association of the stramenopilan protists, the aplanochytrids, with zooplankton of the equatorial Indian Ocean
}

\author{
Varada Damare $^{1,2}$, Seshagiri Raghukumar ${ }^{1,3, *}$ \\ ${ }^{1}$ National Institute of Oceanography, Dona Paula, Goa 403 004, India \\ ${ }^{2}$ Present address: Institut für Marine Biotechnologie, Biotechnikum, Walter Rathenau Strasse 49A, 17489 Greifswald, Germany \\ ${ }^{3}$ Present address: 313 Vainguinnim Valley, Dona Paula, Goa 403 004, India
}

\begin{abstract}
Thraustochytrids and aplanochytrids, belonging to the Labyrinthulomycetes of the Kingdom Stramenopila, have been frequently reported to occur as parasites or symbionts in a number of coastal invertebrates. Given the fact that these protists are widespread in coastal and oceanic waters, it is possible that they are also associated with pelagic zooplankton. This study examines their occurrence in zooplankton from equatorial waters of the Indian Ocean. A total of 171 of 2100 individual specimens of zooplankton yielded Labyrinthulomycetes in culture, the colony morphology and/or life cycles of which corresponded to aplanochytrids. Small-subunit ribosomal DNA (SSU rDNA) sequence analysis of 8 of the isolates placed them in a distinct clade among aplanochytrids, but closest to Aplanochytrium yorkensis or A. kerguelensis. The 8 isolates were further segregated into 2 clusters, corresponding to isolates obtained from 2 different seasons. Biotinylated probes for 2 isolates of $A$. kerguelensis from the 2 different seasons were developed based on internal transcribed spacer (ITS) sequences. In situ hybridization (ISH) of zooplankton using the probes with streptavidin-alkaline phosphatase showed that aplanochytrid cells fed to copepods were grazed and could subsequently be detected in the animals. ISH on natural samples of zooplankton yielded a positive but diffuse reaction in copepods, while cells resembling aplanochytrids were detected within chaetognaths. ISH using streptavidin-peroxidase conjugate lent further support for their presence within chaetognaths. This study suggests the predominant occurrence of $A$. kerguelensis in association with mesozooplankton of the equatorial Indian Ocean, particularly with chaetognaths. Further studies are suggested to determine whether genetically distinct populations of $A$. kerguelensis are associated with chaetognaths in oceanic waters and if such an association is parasitic, mutualistic or commensalistic.
\end{abstract}

KEY WORDS: Stramenopila $\cdot$ Labyrinthulomycetes · Aplanochytrids · Zooplankton · Internal transcribed spacer $\cdot$ In situ hybridization $\cdot$ Biotinylated probes

Resale or republication not permitted without written consent of the publisher

\section{INTRODUCTION}

Stramenopilan protists belonging to the Labyrinthulomycetes, a group comprised of osmoheterotrophic, unicellular thraustochytrids, aplanochytrids and labyrinthulids are extremely common in coastal and oceanic marine environments (Leander \& Porter 2001, Raghukumar 2002). Labyrinthulids are mostly coastal, while thraustochytrids are ubiquitous and abundant in a variety of habitats in coastal and oceanic waters (Kimura et al. 1999, Damare \& Raghukumar 2008). Aplanochytrids have been reported from both coastal and oceanic habitats, but their ecology is poorly known. Thraustochytrids produce high amounts of the $\omega-3$ polyunsaturated fatty acid 'docosahexaenoic acid' (Raghukumar 2008). Since crustacean zooplankton 
require these fatty acids for their growth and reproduction but possess a limited or no ability to synthesize them (Kanazawa et al. 1979a,b, Lubzens et al. 1985, Nichols \& Nichols 2008), Labyrinthulomycetes present in the water column might play an important role in the marine food web by serving as sources of these fatty acids for the zooplankton (Fell \& Newell 1998, Kimura et al. 1999, Raghukumar 2002).

Thraustochytrids and aplanochytrids are known to be associated with invertebrates in a variety of ways. Raghukumar \& Raghukumar (1999) observed thraustochytrids in the faecal pellets of salps. They were found to be endolithic in mollusk shell fragments, especially mussel shells and clam shells (Porter \& Lingle 1992), and were isolated from oyster tissue (Perkins 1973) and surface mucus of the hermatypic coral Fungia granulosa (Harel et al. 2008). Labyrinthuloides haliotidis, now known as Aplanochytrium haliotidis, was reported to cause pathogenic infection in the abalone Haliotis kamtschatkana (Bower 1987, Bower et al. 1989). Thraustochytrids were found to be the most common contaminants while developing cell lines and cultures of a number of invertebrates such as sponges, cnidarians, crustaceans, mollusks, echinoderms and tunicates, indicating some kind of an association (Frank et al. 1994, Hsu et al. 1995, Rinkevich \& Rabinowitz 1997, Rinkevich 1999).

Given the frequent association of Labyrinthulomycetes with invertebrates, it is important to know which of such associations are commensalistic, mutualistic or parasitic in order to understand their role in food web dynamics. In order to do this it is necessary to isolate these organisms from particular invertebrate hosts and to locate them within their host tissues. For example, Raghukumar (1988) detected Ulkenia visurgensis in coelenteron and hydranth of a hydroid in tidal pools using immunofluorescence, an observation that strongly suggests a mutualistic association between the invertebrate and the thraustochytrid. Oligonucleotide probes targeted against the small-subunit ribosomal DNA (SSU rDNA), the 16S rRNA gene in the case of bacteria and the 18S rRNA gene in the case of eukaryotes have emerged as powerful tools to detect microorganisms in their natural environment in recent years. The internal transcribed spacer (ITS) portion of the rRNA gene is highly variable between species and often even strains and can be used to design probes to detect organisms at species level.
There are few reports on the associations of Labyrinthulomycetes with zooplankton in the oceanic environment. In the present study we have attempted to study the associations of Labyrinthulomycetes with zooplankton of the equatorial Indian Ocean by isolating them from these invertebrates and characterizing them taxonomically. In addition, we have attempted in situ detection of aplanochytrid cells in zooplankton, with the help of oligonucleotide probes, directed against their ITS sequences.

\section{MATERIALS AND METHODS}

Isolation of Labyrinthulomycetes from zooplankton. Mesozooplankton were collected during 2 cruises to the equatorial Indian Ocean on board ORV 'Sagar Kanya' (Cruise Numbers SK196 during September 2003 and SK212 during October 2004) using a multiple plankton net (MPN, MultiNet Type Midi with $200 \mu \mathrm{m}$ mesh nets, Hydrobios). The location of the sampling stations is given in Fig. 1. Specimens were collected from different depth ranges, ranging from the surface to $1000 \mathrm{~m}$. Zooplankton specimens were rinsed several times with sterile seawater and plated on Modified Vishniac (MV) Agar medium (Porter 1990) supplemented with $400000 \mathrm{U}$ procaine penicillin, $0.075 \mathrm{~g}$ streptomycin (Trade name Ambystrin-S) and $1 \%$ fetal bovine serum.

Isolation of DNA from aplanochytrid cultures. Isolation of whole genomic DNA of the isolates was carried

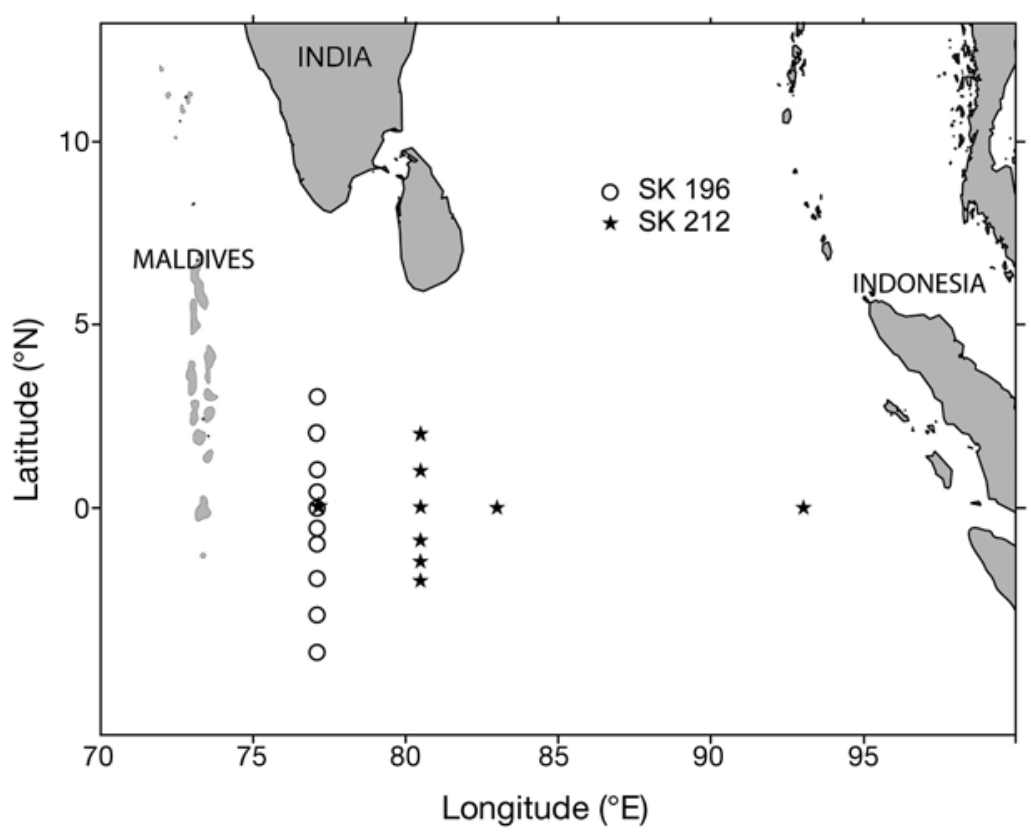

Fig. 1. Area in the equatorial Indian Ocean where zooplankton were collected by deploying multiple plankton nets during cruises SK196 (September 2003) and SK212 (October 2004) 
out by a modification of the phenol-chloroform:isoamyl alcohol method (Sambrook et al. 1989). Cell pellets obtained after growing the isolates for 5 to $7 \mathrm{~d}$ in $\mathrm{MV}$ broth in shake cultures were washed with sterile seawater in a microcentrifuge tube and subjected to 3 cycles of freezing and thawing using liquid nitrogen. Lysis buffer (2\% Triton X100, $1 \%$ sodium dodecyl sulphate, $100 \mathrm{mM}$ sodium chloride, $10 \mathrm{mM}$ Tris hydrochloride pH 8.0, 1 mM EDTA) was added, followed by 1:1 phenol and chloroform: isoamyl alcohol. Sterile glass beads of 150 to $350 \mu \mathrm{m}$ size (Sigma) were added and vortexed until the entire contents of the tube turned viscous in nature. The tubes were stored at $-20^{\circ} \mathrm{C}$ for better precipitation. The pellets were collected by centrifugation at $12000 \mathrm{rpm}(14122 \times \mathrm{g})$ for 10 min under cold conditions, washed once with cold $70 \%$ ethanol and dried using a centrifugal vacuum concentrator (Biotron Ecospin 314, S. No. Ec-050310). The dried DNA pellets were dissolved in sterile TE buffer (10 mM Tris-Cl, pH 8.0; 1mM EDTA, pH 8.0) and checked for purity by electrophoresis using $0.8 \%$ agarose gel. DNA concentration was assessed spectrophotometrically by determining the optical density $\mathrm{OD}_{260} / \mathrm{OD}_{280}$ ratio. The DNA was stored at $-20^{\circ} \mathrm{C}$ until it was amplified by polymerase chain reaction (PCR). All PCR amplifications were carried out with final concentrations of $7.5 \mathrm{pM}$ primer each, $100 \mu \mathrm{M}$ dNTP mix, $1 \times$ PCR buffer containing $1.5 \mathrm{mM} \mathrm{MgCl}_{2}$, and $1 \mathrm{U}$ Taq polymerase in a BioRad Thermal Cycler (S. No. AL100938).

$18 \mathrm{~S}$ rDNA identification of the isolates and phylogenetic analysis. Two external primers designed by Honda et al. (1999) (18S001 and 18S13) and 2 universal internal primers (NS3 and NS4; White et al. 1990) were used to amplify the $18 \mathrm{~S}$ rDNA regions of the isolates. PCR conditions were denaturation at $94^{\circ} \mathrm{C}$ for $4 \mathrm{~min}$, followed by 30 cycles of denaturation $94^{\circ} \mathrm{C}$ for $50 \mathrm{~s}$, annealing at $59.5^{\circ} \mathrm{C}$ for $50 \mathrm{~s}$ for Set I (18S001 [fwd] and $\mathrm{NS} 4$ [rev]) or $62.5^{\circ} \mathrm{C}$ for $50 \mathrm{~s}$ for Set II (NS3 [fwd] and $18 \mathrm{~S} 13$ [rev]) and extension at $72^{\circ} \mathrm{C}$ for $1 \mathrm{~min}$, followed by a final extension step of $72^{\circ} \mathrm{C}$ for $10 \mathrm{~min}$. The amplified PCR products were purified using Montage PCR Clean Up Kit (Millipore) and sequenced. The $18 \mathrm{~S}$ rDNA sequences obtained were deposited in the GenBank (Table 1). Phylogenetic trees based on the $18 \mathrm{~S}$ rDNA sequences were generated using the neighbourjoining (NJ), minimum-evolution (ME) and the maximum-parsimony (MP) methods using MEGA version 4. The evolutionary distances in NJ and ME trees were computed using the maximum composite likelihood method. The MP tree was obtained using the closeneighbor-interchange algorithm. Sources of the other sequences, rooted to stramenopiles were obtained from National Center for Biotechnology Information (NCBI) database.
Table 1. Details of 18S and internal transcribed spacer (ITS) ribosomal DNA (rDNA) sequences of aplanochytrids isolated from zooplankton of the equatorial Indian Ocean

\begin{tabular}{|ccccc|}
\hline rDNA type & Isolate & $\begin{array}{c}\text { Period of } \\
\text { isolation }\end{array}$ & $\begin{array}{c}\text { Sequence } \\
\text { size (bp) }\end{array}$ & $\begin{array}{c}\text { GenBank } \\
\text { accession no. }\end{array}$ \\
\hline 18S rDNA & S1961 & Sep 2003 & 1682 & EU851167 \\
& S1962 & Sep 2003 & 1353 & EU851174 \\
& S19610 & Sep 2003 & 1675 & EU851168 \\
& S2122 & Oct 2004 & 1644 & EU851172 \\
& S2124 & Oct 2004 & 1683 & EU851169 \\
& S2125 & Oct 2004 & 1682 & EU851170 \\
& S2128 & Oct 2004 & 1731 & EU851173 \\
& S2129 & Oct 2004 & 1681 & EU851171 \\
ITS rDNA & S1961 & Sep 2003 & 556 & EU872090 \\
& S1963 & Sep 2003 & 503 & EU872091 \\
& S19610 & Sep 2003 & 503 & EU872092 \\
& S2122 & Oct 2004 & 552 & - \\
& S2124 & Oct 2004 & 447 & EU872093 \\
& S2128 & Oct 2004 & 572 & - \\
& S2129 & Oct 2004 & 562 & - \\
\hline
\end{tabular}

PCR amplification of ITS rDNA and sequencing. The ITS region of ribosomal DNA of 7 isolates was amplified using universal ITS primers (ITS1 and ITS4) designed by White et al. (1990). The reaction conditions were $94^{\circ} \mathrm{C}$ for $4 \mathrm{~min}$, followed by 30 cycles of $94^{\circ} \mathrm{C}$ for $50 \mathrm{~s}, 57^{\circ} \mathrm{C}$ for $45 \mathrm{~s}$ and $72^{\circ} \mathrm{C}$ for $1 \mathrm{~min}$, with a final elongation step of $72^{\circ} \mathrm{C}$ for $7 \mathrm{~min}$. The amplified PCR products were purified using Montage PCR Clean Up Kit (Millipore) and sequenced. Purified PCR products for which sequencing was unsatisfactory were cloned using TOPO Cloning Kit (Invitrogen) and the plasmid from the transformants was extracted by the alkaline lysis method (Birnboim \& Doly 1979) and sequenced. The sequences obtained were deposited in GenBank (Table 1).

Design of oligonucleotide probes. A total of 14 ITS sequences were used for the alignment. This consisted of 7 isolates of aplanochytrids obtained from zooplankton of the equatorial Indian Ocean in the present study and 7 of other organisms belonging to the Kingdom Straminipila, downloaded from the NCBI database. Amongst the Labyrinthulomycetes, ITS sequences of only labyrinthulid quahog parasite (QPX) and Thraustochytrium aureum are available in the NCBI database out of which the sequences with accession numbers DQ641197, FJ533161 and FJ533163 were used in the present study. Four sequences of other organisms belonging to Kingdom Straminipila were downloaded for comparison. These 4 sequences showed 70 to $80 \%$ similarity with the aplanochytrid ITS sequences of the present study but only 7 to $24 \%$ of query coverage. These sequences belonged to Sellaphora AJ544676, Hyaloperonospora parasitica EU049281, Peronospora tribulina AY531414 and Nitzschia AY574377. 
Multiple alignment of all sequences was carried out using ClustalW. The sequences which showed consensus regions only among the aplanochytrids and minimal or nil similarity with other organisms were chosen for designing probes for the aplanochytrids. These consensus sequences were analysed using Vector NTI 10 software (Invitrogen). Based on the analysis, a total of 4 probes, consisting of one forward and one reverse primer for 2 isolates, S1961 and S2124, were designed (Table 2). Primer oligonucleotides were obtained from Sigma Genosys. All primers were biotinylated at the 5 ' end.

Confirmation of probe specificity. PCR amplification of the DNA of 8 aplanochytrid isolates obtained from zooplankton of equatorial Indian Ocean as well as 3 thraustochytrid isolates (PRA-147 [ATCC], Z7 and DP7) present in the culture collection of the National Institute of Oceanography, Goa, India, was carried out using the designed set of primers, i.e. S61F1-S61R1 and 138F1-138R1, respectively, to check the specificity of the primers designed towards the 2 aplanochytrids. The annealing temperature conditions were optimized for both the primer sets by carrying out a gradient PCR in a Peltier Thermal Cycler (MJ Research, PTC-200, S. No. AL083846). The temperature gradient ranging from $45^{\circ}$ to $65^{\circ} \mathrm{C}$ was checked. The optimal conditions for the 2 primer sets were $94^{\circ} \mathrm{C}$ for $4 \mathrm{~min}$, followed by 30 cycles of denaturation at $94^{\circ} \mathrm{C}$ for $40 \mathrm{~s}$, annealing at $56^{\circ} \mathrm{C}$ for $50 \mathrm{~s}$ for the former primer set and $60^{\circ} \mathrm{C}$ for $50 \mathrm{~s}$ for the latter and extension at $72^{\circ} \mathrm{C}$ for $1 \mathrm{~min}$, with a final elongation step of $72^{\circ} \mathrm{C}$ for $6 \mathrm{~min}$.

The specificity was further confirmed by Southern hybridization of the amplified bands with the respective probes using the Southern Hybridization Kit (Bangalore Genei). Hybridization and post-hybridization reactions were carried out on the membrane as well as on the gel to check if all the bands had blotted over the membrane as per the manufacturer's instructions. The bands were hybridized with the probe S61F1 for isolates S1961, S1963 and S19610 and the probe 138F1 for isolates S2122, S2124, S2128 and S2129.

Standardization of pretreatment conditions for in situ hybridization (ISH) of whole aplanochytrid cells. Permeabilization conditions were optimized using

Table 2. Sequences of probes designed for 2 isolates of Aplanochytrium kerguelense from zooplankton of the equatorial Indian Ocean. Probes designed by alignment of 7 isolates from the present study with 7 other organisms from the Kingdom Stramenopila

\begin{tabular}{|lcrcc|}
\hline Isolate no. & Probe & Length & Sequence & Type \\
\hline S1961 & S61F1 & 19 & 5'-TAATCCATTTCTAATTCCG & Forward \\
& S61R1 & 19 & 5'-TACATAAAAACCCAAAATC & Reverse \\
S2124 & 138F1 & 20 & 5'-GCTGTCGCCTGTTCTGATTG & Forward \\
& 138R1 & 20 & 5'-ACATACTTGCGTACATATTG & Reverse \\
\hline
\end{tabular}

cells of isolates S1961 and S19610. Five day old cells of the isolates grown in MV medium were harvested and suspended in phosphate-buffered saline (PBS) containing formalin up to $2 \%$ concentration and stored under refrigeration till further use. Four different permeabilization techniques were tried: (1) cells were incubated overnight with Triton X100 in order to reduce hydrophobic interactions (Thimm \& Tebbe 2003); (2) cells were subjected to repeated freeze and thaw in liquid nitrogen to facilitate disruption of cells through ice crystal formation (Biegala et al. 2003); (3) cells were incubated for 5 min with dithiothreitol (DTT), to reduce disulphide bonds of membrane proteins (Moter \& Göbel 2000); cells permeabilized after these 3 treatments were then smeared on glass slides coated with double-sided adhesive tape (La Cono \& Urzì 2003) and also on Polyprep slides (Sigma) (Smolina et al. 2007) and dehydrated in an ethanol series; (4) cells fixed with formalin were treated with 1 M DTT for $5 \mathrm{~min}$, followed by washing with distilled water and final suspension in $1 \mathrm{M}$ sorbitol. These cells, which were suspended in sorbitol, were transferred in a cuvette and given an electric pulse of $2500 \mathrm{~V}$ for $\sim 5 \mathrm{~ms}$ in a Gene Pulser Xcell ${ }^{\mathrm{TM}}$ (BioRad, S. No. 617BR105105) as per the protocol mentioned for eukaryotic cells in the Gene Pulser Xcell ${ }^{\mathrm{TM}}$ manual.

Standardization of ISH. ISH was standardized with whole aplanochytrid cells using the Southern Hybridization Kit, following the manufacturer's instructions. The probes S61F1 and S61R1 were used separately at a final concentration of $5 \mathrm{pmol} \mathrm{ul}^{-1}$. Two different probe conjugates were used for incubation of 20 to $45 \mathrm{~min}$, namely streptavidin-alkaline phosphatase (ALP) (Sigma) and streptavidin-peroxidase conjugates (Sigma). The cells were then incubated in respective substrate solutions until they took up the colour of the reaction. The substrate used for ALP was 5-bromo-4chloro-3-indolyl phosphate/nitro blue tetrazolium (BCIP/NBT) (Sigma), which produced blue colour in the cells, while the substrate used for peroxidase was 3,3'-diaminobenzidine (DAB) tetrahydrochloride hydrate (Sigma), giving purple to dark red colouration to the cells. The incubation time of cells in the substrate varied from 3 to $12 \mathrm{~h}$ for ALP and peroxidase respectively.

Application of probes to field samples. Aggregates from the equatorial Indian Ocean: Aggregates from water samples of the equatorial Indian Ocean, collected along with the mesozooplankton using multiple plankton nets, were subjected to different pre-treatments, namely electroporation and air-drying over Polyprep slides prior to ISH with streptavidin-alkaline phosphatase conjugate. 
Control experiment using zooplankton fed with aplanochytrids: The efficiency of the standardized methodology of permeabilization and hybridization using aplanochytrid cells was examined on zooplankton specimens. Mesozooplankton were sampled from Dona Paula Bay using a zooplankton net of mesh size $200 \mu \mathrm{m}$. Approximately 7 or 8 live specimens of mesozooplankton were kept in 5 separate beakers each under aeration in the laboratory and starved for $6 \mathrm{~h}$. Cells of the aplanochytrid S1961 were fed to each experimental beaker. Cells were added up to twice the concentration of Labyrinthulomycetes found in natural

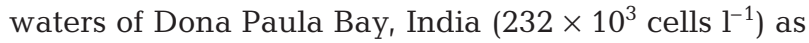
estimated independently using epifluorescence microscopy (Raghukumar \& Schaumann 1993). A beaker each was sampled at $4,6,10,15$ and $24 \mathrm{~h}$ by fixing the entire contents with $2 \%$ formaldehyde. The specimens from each beaker were transferred to microcentrifuge tubes. Permeabilization of the entire zooplankton specimens presumably containing the aplanochytrid cells was then carried out as follows. The specimens were treated with $1 \mathrm{M}$ DTT for $5 \mathrm{~min}$ in order to reduce disulphide bonds in membrane proteins. They were then washed twice with distilled water and once with $1 \mathrm{M}$ sorbitol and finally suspended in $1 \mathrm{M}$ sorbitol, which acts as osmotic stabilizer. The entire specimens were then transferred to a cuvette and given an electric pulse of $2500 \mathrm{~V}$ for $\sim 5 \mathrm{~ms}$ as given above. The specimens were then subjected to ISH under the same conditions as mentioned before for the whole aplanochytrid cells using streptavidin-ALP conjugate.

ISH for aplanochytrids in natural zooplankton population from the equatorial Indian Ocean: Zooplankton samples collected using the multiple plankton net during the 2 cruises on board ORV Sagar Kanya SK 212 (October 2004) and SK 228 (September 2006) from the water column of the equatorial Indian Ocean were preserved in formalin at $2 \%$ concentration in a refrigerator. ISH was carried out using S61F1 and 138F1 probes individually. Permeabilization was achieved through electroporation, as mentioned earlier, and hybridization was carried out using the strepatividn-ALP conjugate. After incubation with substrate solution for 1 to $2 \mathrm{~h}$, the specimens were transferred to distilled water and then on to a glass slide and observed using bright field microscopy (Olympus BX60). Specimens with blue colouration were noted as positive. Photographs were captured using an Olympus DP70 digital camera.

ISH for aplanochytrids in chaetognaths, following in situ PCR. Specimens of chaetognaths from the Indian Ocean collected and fixed as above were washed with PBS and either dried under vacuum using a centrifugal vacuum concentrator (Biotron Ecospin 314, S. No. Ec-050310) or suspended in $1 \mathrm{M}$ sorbitol and electroporated before carrying out in situ PCR. A total of $50 \mu$ l of PCR buffer was added to each specimen in the PCR tube. In situ PCR using the 2 different sets of primers (i.e. S61F1-S61R1 and 138F1-138R1) was carried out separately using BioRad Thermal Cycler (S. No. AL100938). PCR cycles consisted of 30 cycles of denaturation at $94^{\circ} \mathrm{C}$ for $40 \mathrm{~s}$, primer annealing $\left(56^{\circ} \mathrm{C}\right.$ for $\mathrm{S} 61 \mathrm{~F} 1-\mathrm{R} 1$ primer set or $60^{\circ} \mathrm{C}$ for the $138 \mathrm{~F} 1-\mathrm{R} 1$ primer set) for $50 \mathrm{~s}$, and extension at $72^{\circ} \mathrm{C}$ for $60 \mathrm{~s}$. The specimens were then subjected to ISH following the methods for natural zooplankton as given above and using strepavidin-ALP conjugate.

ISH of chaetognath specimens with streptavidinperoxidase conjugate. Chaetognath specimens were subjected to ISH using streptavidin-peroxidase conjugate. In addition to skimmed milk powder, bovine serum albumin (BSA) was used as an alternate blocking agent at concentration similar to that of skimmed milk powder used for all the earlier experiments. The effect of BSA as blocking agent was checked in the presence and absence of $0.05 \%$ Tween 20 .

\section{RESULTS}

\section{Isolation of Labyrinthulomycetes from zooplankton of the equatorial Indian Ocean}

A total of 2100 zooplankton specimens, collected from 76 multiple plankton net samples and obtained from 19 stations during 2 cruises, were plated on to MV medium for isolating thraustochytrids and aplanochytrids (Table 3). Out of this, a total of 171 specimens, corresponding to $8.14 \%$, were positive for the protists. Labyrinthulomycetes were isolated from all the depths, ranging from 0 to $1000 \mathrm{~m}$.

Out of the total 171 colonies obtained, 8 isolates that survived after repeated subculturing were maintained for further studies. Five of these were isolated during September 2003 and the remaining 9 during October 2004. Eight of these isolates were further characterized based on their 18S rDNA sequences.

\section{Molecular identification of aplanochytrids and phylogenetic analysis}

The 18S rDNA sequences of the 8 isolates from the equatorial Indian Ocean ranged in size from 1353 to $1731 \mathrm{bp}$ (Table 1). BLAST analysis of these sequences showed 98 to $100 \%$ similarity to Aplanochytrium kerguelensis and A. stocchinoi.

Phylogenetic analysis carried out using 3 clustering algorithms (NJ, ME and MP) resulted in phylogenetic trees with similar topologies (Figs. S1 \& S2 in the Supplementary Materials; www.int-res.com/articles/ 
Table 3. Sampling locations in the equatorial Indian Ocean and depth ranges at which zooplankton samples were collected for isolation of Labyrinthulomycetes. Depth ranges in bold indicate samples from which protists wererecovered in culture

\begin{tabular}{|c|c|c|c|}
\hline $\begin{array}{l}\text { Time } \\
\text { (h) }\end{array}$ & Latitude & Longitude & Depths (m) \\
\hline \multicolumn{4}{|c|}{ September 2003 (Cruise SK196) } \\
\hline $07: 50$ & $3^{\circ} \mathrm{N}$ & $77^{\circ} \mathrm{E}$ & $0-40,40-200,200-300,300-500$ \\
\hline $02: 30$ & $2^{\circ} \mathrm{N}$ & $77^{\circ} \mathrm{E}$ & $0-40,40-200,200-300,300-500$ \\
\hline $11: 00$ & $1^{\circ} \mathrm{N}$ & $77^{\circ} \mathrm{E}$ & $0-40, \mathbf{4 0}-\mathbf{2 0 0}, 200-300,300-500$ \\
\hline 19:00 & $0.5^{\circ} \mathrm{N}$ & $77^{\circ} \mathrm{E}$ & $\mathbf{0}-\mathbf{7 0}, \mathbf{7 0}-\mathbf{2 0 0}, 200-300,300-500$ \\
\hline $07: 30$ & $0^{\circ} \mathrm{Eq}$ & $77^{\circ} \mathrm{E}$ & $0-40,40-200,200-300,300-500$ \\
\hline $01: 15$ & $0.5^{\circ} \mathrm{S}$ & $77^{\circ} \mathrm{E}$ & $0-30,30-200,200-300,300-500$ \\
\hline $03: 50$ & $1^{\circ} \mathrm{S}$ & $77^{\circ} \mathrm{E}$ & 0-40, 40-200, 200-300, 300-500 \\
\hline $01: 15$ & $2^{\circ} \mathrm{S}$ & $77^{\circ} \mathrm{E}$ & $0-30,30-200,200-300,300-500$ \\
\hline 06:00 & $3^{\circ} \mathrm{S}$ & $77^{\circ} \mathrm{E}$ & $0-40, \mathbf{4 0}-\mathbf{2 0 0}, 200-300,300-500$ \\
\hline $17: 00$ & $4^{\circ} \mathrm{S}$ & $77^{\circ} \mathrm{E}$ & $\mathbf{0}-\mathbf{3 0}, 30-200,200-300,300-500$ \\
\hline \multicolumn{4}{|c|}{ October 2004 (Cruise SK212) } \\
\hline $21: 30$ & $0^{\circ} \mathrm{Eq}$ & $77^{\circ} \mathrm{E}$ & $0-60,60-200,200-300,300-500$ \\
\hline $00: 20$ & $2^{\circ} \mathrm{N}$ & $80.5^{\circ} \mathrm{E}$ & $0-20,20-200,200-300,300-500$ \\
\hline $23: 30$ & $1^{\circ} \mathrm{N}$ & $80.5^{\circ} \mathrm{E}$ & $0-30, \mathbf{3 0}-\mathbf{2 0 0}, 200-300, \mathbf{3 0 0}-\mathbf{5 0 0}$ \\
\hline $14: 30$ & $0^{\circ} \mathrm{Eq}$ & $80.5^{\circ} \mathrm{E}$ & $\mathbf{0 - 3 8}, \mathbf{3 8}-\mathbf{2 0 0}, 200-500, \mathbf{5 0 0 - 1 0 0 0}$ \\
\hline $16: 00$ & $0^{\circ} \mathrm{Eq}$ & $83^{\circ} \mathrm{E}$ & $0-30,30-300,300-500,500-1000$ \\
\hline $08: 30$ & $1^{\circ} \mathrm{S}$ & $80.5^{\circ} \mathrm{E}$ & $0-60,60-200,200-500,500-1000$ \\
\hline $13: 40$ & $1.5^{\circ} \mathrm{S}$ & $80.5^{\circ} \mathrm{E}$ & 0-60, 60-200, 200-300, 300-500 \\
\hline $22: 15$ & $2^{\circ} \mathrm{S}$ & $80.5^{\circ} \mathrm{E}$ & $\mathbf{0}-\mathbf{6 0}, \mathbf{6 0}-\mathbf{2 0 0}, 200-300, \mathbf{3 0 0}-\mathbf{5 0 0}$ \\
\hline $14: 00$ & $0^{\circ} \mathrm{Eq}$ & $93^{\circ} \mathrm{E}$ & $\mathbf{0}-\mathbf{3 0}, 30-300,300-500,500-1000$ \\
\hline
\end{tabular}

suppl/m399p053_app.pdf). A representative of the 3 phylogenetic trees (NJ tree) is presented in Fig. 2. Three distinct clades of the Labyrinthulomycetes were noticed. The first comprised the thraustochytrids Sicyoidochytrium minutum, Botryochytrium radiatum, Parietichytrium sarkarianum, Thraustochytrium striatum, Schizochytrium aggregatum and Ulkenia visurgensis, which formed a separate clade from the rest of the Labyrinthulomycetes, with a high bootstrap value of $100 \%$. The other members of the Labyrinthulomycetes formed 2 clades, the first comprising the labyrinthulid Labyrinthula sp. and the second comprising the aplanochytrids supported by 64 to $69 \%$ bootstrap values. All 8 isolates obtained from oceanic zooplankton in the present study grouped with Aplanochytrium yorkensis and A. kerguelensis and separated from the rest of the aplanochytrids. Isolate S1962 was the closest to A. yorkensis and Aplanochytrium 367045 in all 3 trees. In the topology, isolates obtained during the SK212 cruise in October 2004 formed a clade distinct from the aplanochytrids obtained during the SK196 cruise, with bootstrap values of $38 \%$ in the NJ and ME trees.

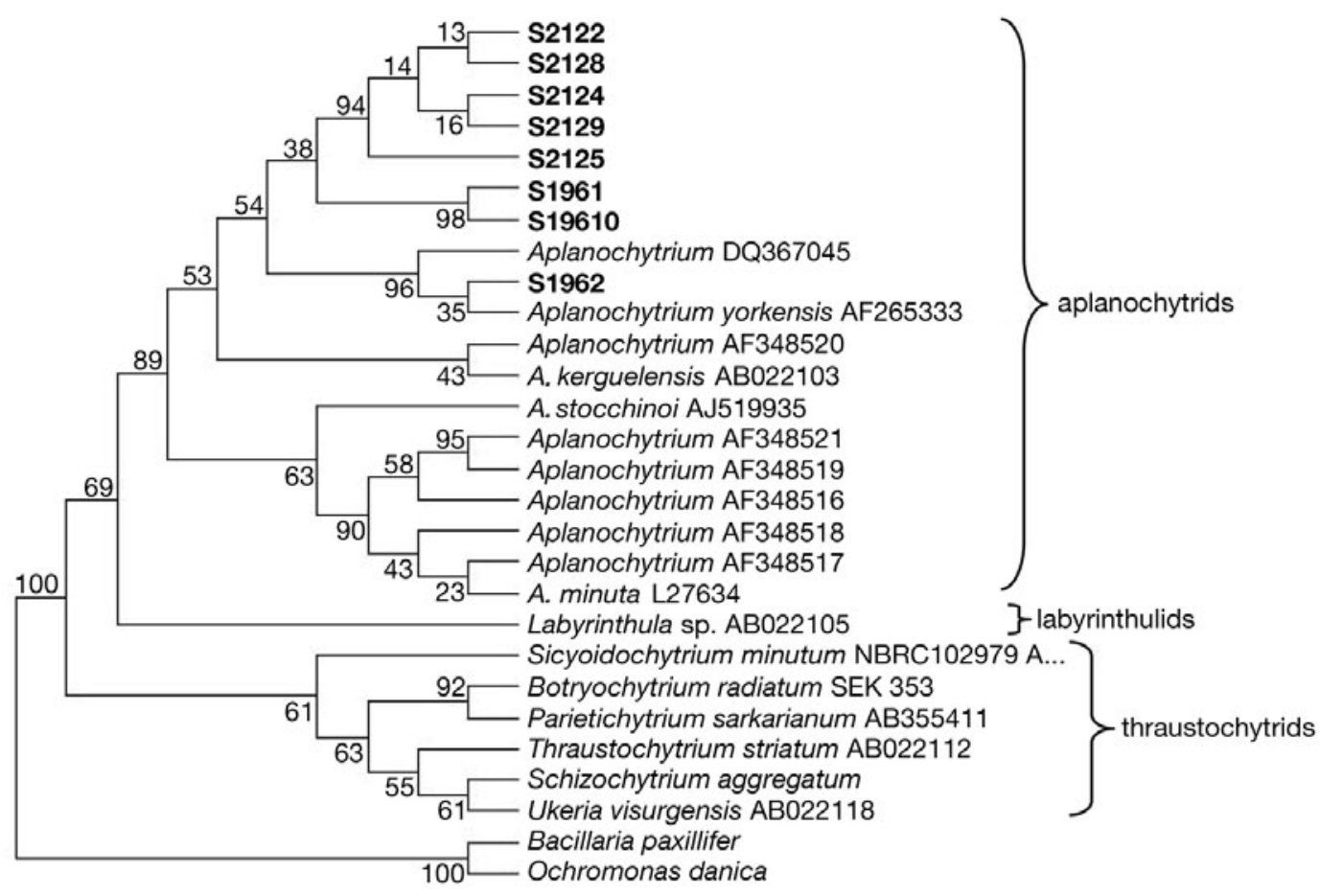

Fig. 2. Neighbour-joining (NJ) tree of 18S rDNA of aplanochytrids of the present study (bold) with Bacillaria paxillifer (Accession no. M87325) and Ochromonas danica (Accession no. M32704 J02950) as outgroups 


\section{Alignment of ITS sequences and designing of probes}

The ITS rDNA PCR products of the 7 isolates studied ranged in size from 447 to $572 \mathrm{bp}$ (Table 1). Since the $18 \mathrm{~S}$ rDNA phylogenetic trees suggested that the aplanochytrids from the Indian Ocean were distributed as 2 distinct clusters, the probes were designed against 2 isolates, 1 from each cluster. Probe design analysis resulted in choosing S1961 from the SK196 cruise and S2124 from the SK212 cruise as the best possible candidates for the probe. Two sets of primers were designed against each of the 2 isolates. (Table 2, Fig. S3; www.int-res.com/articles/suppl/m399p053_app.pdf).

\section{Confirmation of probe specificity}

PCR amplification with the designed set of primers showed that primer set S61F1-S61R1 amplified DNA of all the isolates obtained from the September 2003 cruise, namely S1961, S1963 and S19610. However, they did not amplify the DNA of the isolates obtained

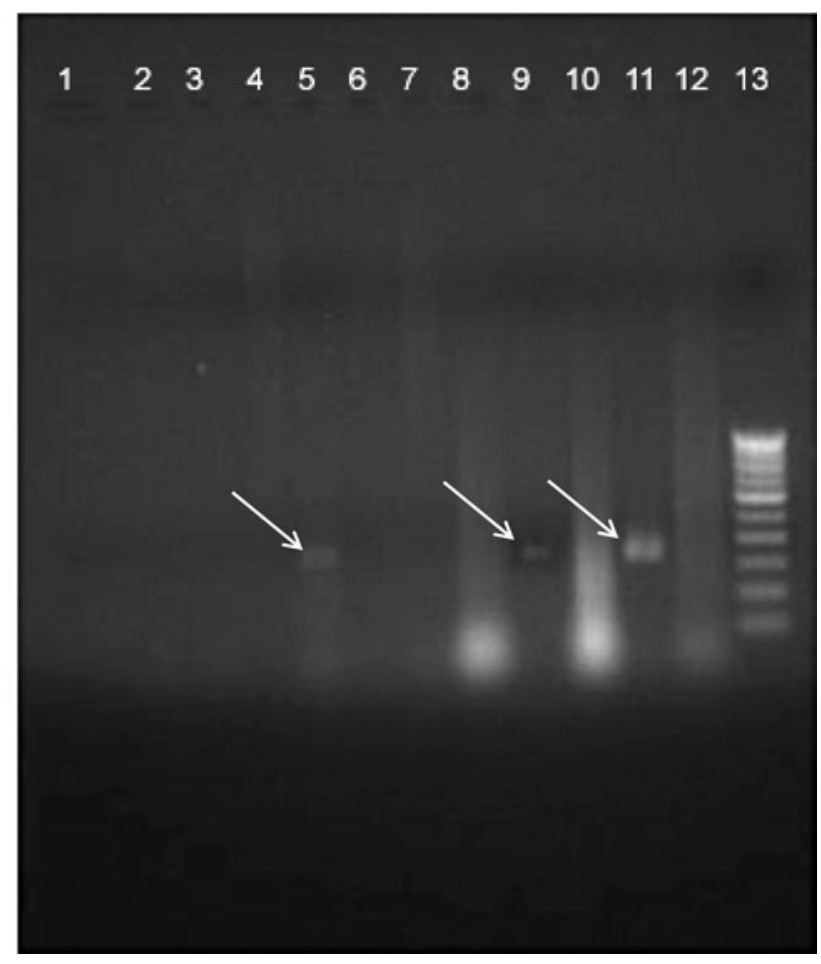

Fig. 3. Agarose gel electrophoresis of PCR-amplified products using S61F1-S61R1 primer set of aplanochytrids from the equatorial Indian Ocean (Lanes 1: S1962, 3: S2122, 5: S19610, 6: S2124, 7: S2129, 8: S2128, 9: S1963 and 11: S1961) and thraustochytrids from the National Institute of Oceanography (NIO) culture collection. (Lanes 2: Z7, 4: CW1, 10:DP7). Lane 12: negative control; Lane 13: $1 \mathrm{~kb}$ DNA ladder. Bands produced by PCR amplification shown by arrows from the October 2004 cruise (Fig. 3). Similarly, primer set 138F1-138R1 amplified DNA of S2122, S2124, S2128 and S2129, which had been isolated during the October 2004 cruise (Fig. 4), but did not amplify the DNA of the isolates obtained from the September 2003 cruise. Southern hybridization carried out using S61F1 probe on the amplified product of the isolates S1961, S1963 and S19610 for the first primer set and using 138F1 probe on the amplified product of the isolates S2122, S2124, S2128 and S2129 for the second primer set using streptavidin-ALP conjugate produced blue bands on the membrane with BCIP/NBT thus showing clear positive signals (Fig. 5).

\section{Standardization of pretreatment conditions for ISH of whole aplanochytrid cells}

The 4 different permeabilization protocols tried prior to ISH of aplanochytrid cells using streptavidin-ALP conjugate showed positive results to varying degrees depending on the protocol used. Cells smeared on

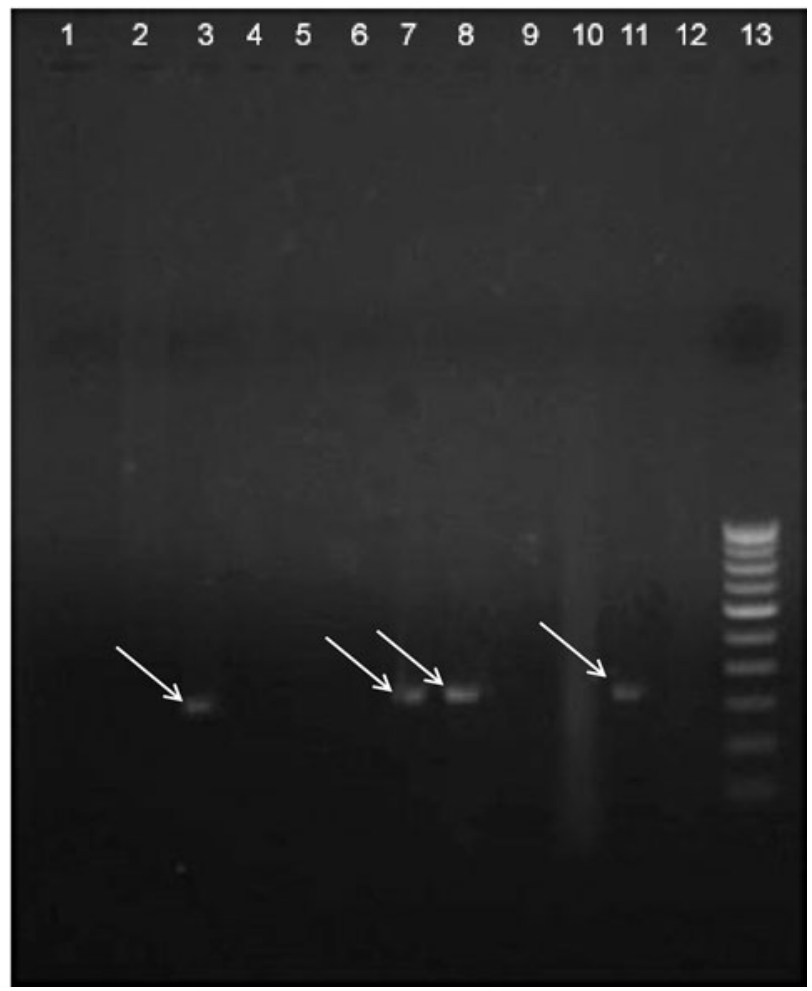

Fig. 4. Agarose gel electrophoresis of PCR-amplified products using 138F1-138R1 primer set of aplanochytrids from the equatorial Indian Ocean (Lanes 1: S1962, 3: S2122, 5: S19610, 6: S1961, 7: S2129, 8: S2128, 9: S1963 and 11: S2124) and thraustochytrids from the National Institute of Oceanography (NIO) culture collection (Lanes 2: Z7, 4: CW1, 10: DP7). Lane 12: negative control; Lane 13: $1 \mathrm{~kb}$ DNA ladder. Bands produced by PCR amplification shown by arrows 


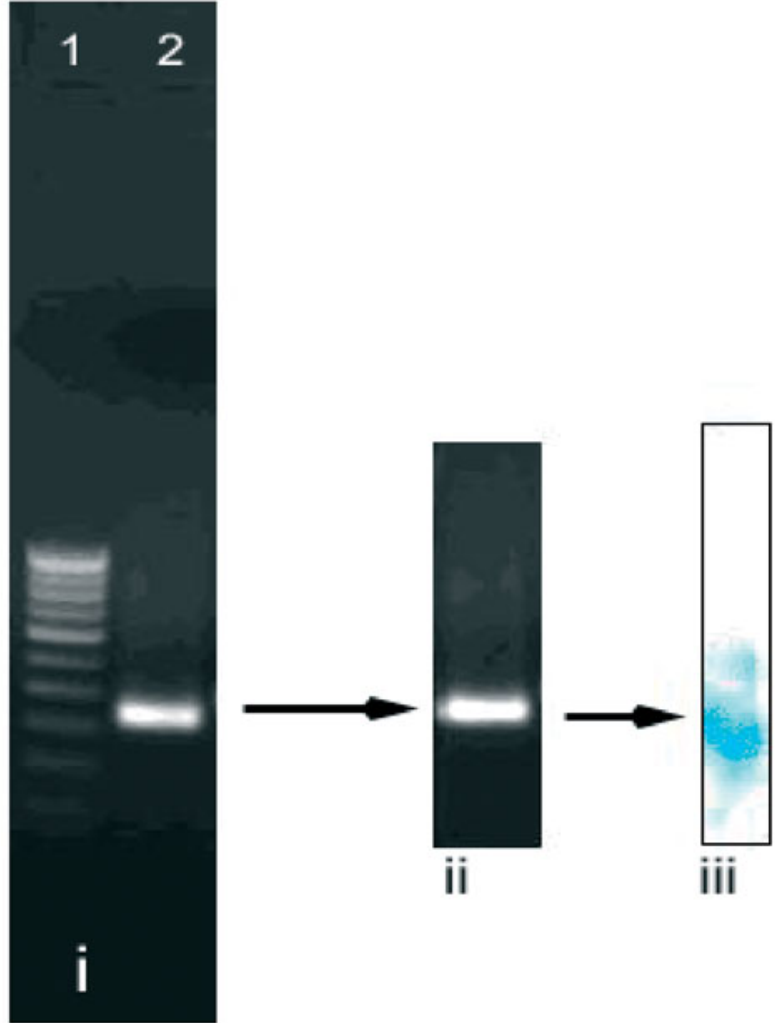

Fig. 5. Southern hybridization of S1961 amplified product using a S61F1-S61R1 primer set as seen stepwise: (i) amplified PCR product of approximately $350 \mathrm{bp}$ in length in agarose gel electrophoresis (Lane 1: $1 \mathrm{~kb}$ DNA ladder, 2: S1961 PCR product); (ii) portion of the gel containing the band cut prior to electroblotting; and (iii) band blotted on nylon membrane visualized by hybridization reaction

slides were not easily retained and were mostly washed off. Secondly, not all cells pretreated in this way showed the positive blue colour after reaction with streptavidin-conjugated alkaline phosphatase and substrate (Fig. 6a). Electroporation of cells to allow permeabilization provided more consistent results. All the cells treated in this way were stained blue but with different intensities (Fig. 6b). Thus, young cells stained dark as compared to older ones. Therefore, electroporation was used for permeabilization before ISH for the other reactions that followed.

Electroporation of formalin-fixed cells of aplanochytrid S1961 followed by ISH with streptavidinperoxidase conjugate consistently produced dark redstained cells after incubation with DAB hydrochloride hydrate, thus displaying positive results (Fig. 7). The positive reaction was seen after $3 \mathrm{~h}$ of incubation with the substrate irrespective of the time of incubation with the conjugate.

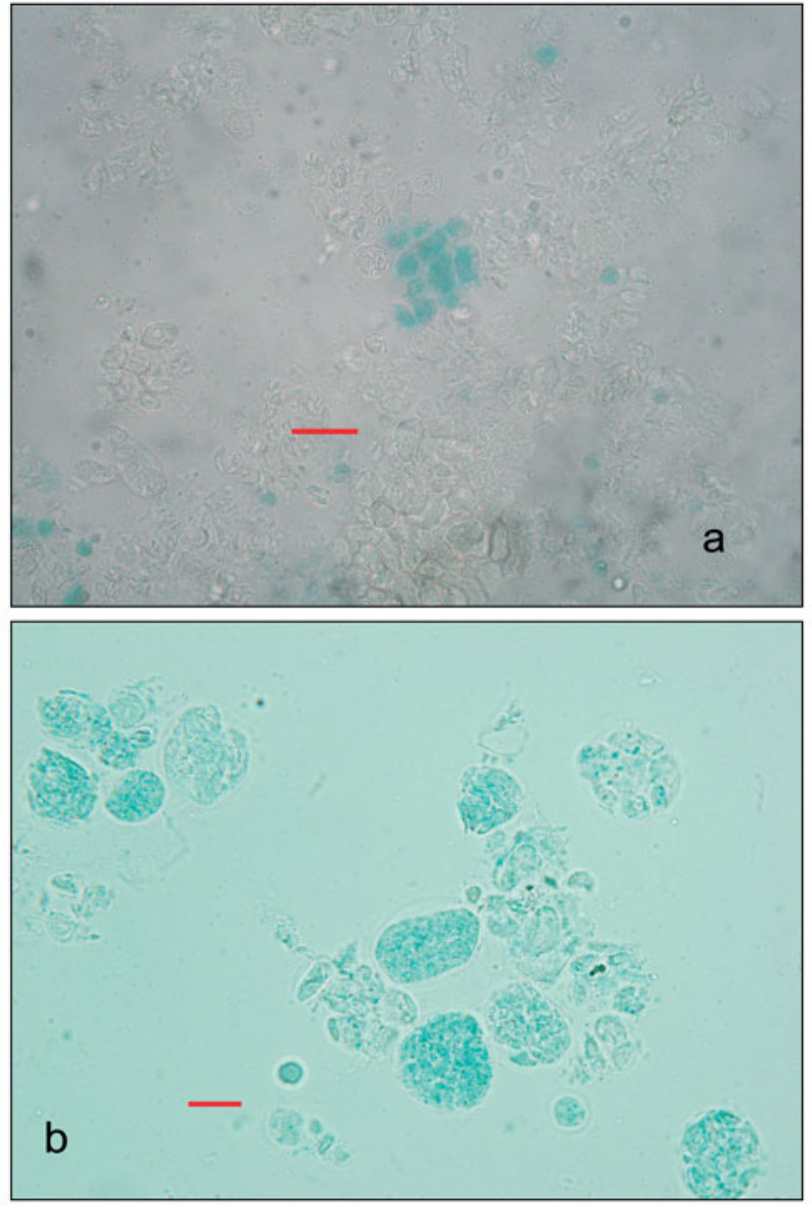

Fig. 6. Aplanochytrid S1961 pretreated by (a) overnight incubation in Triton X100 and (b) electroporation, showing positive reaction for in situ hybridization using biotinylated probes and strepatividin-conjugated alkaline phosphatase. Scale bars $=10 \mu \mathrm{m}$

\section{ISH of field samples using probes}

\section{Aggregates from the water column}

The pretreatments of electroporation as well as airdrying revealed the presence of aplanochytrid probepositive cells attached to the aggregates (Fig. 8). These cells were globose and measured 5 to $20 \mu \mathrm{m}$ in diameter. The cells were generally present scattered in the aggregates.

\section{Zooplankton samples fed with aplanochytrids}

Zooplankton specimens that were fed with cells of the aplanochytrid S1961 for different time intervals were permeabilized using electroporation and subjected to ISH. Aplanochytrid cells that reacted to ISH 


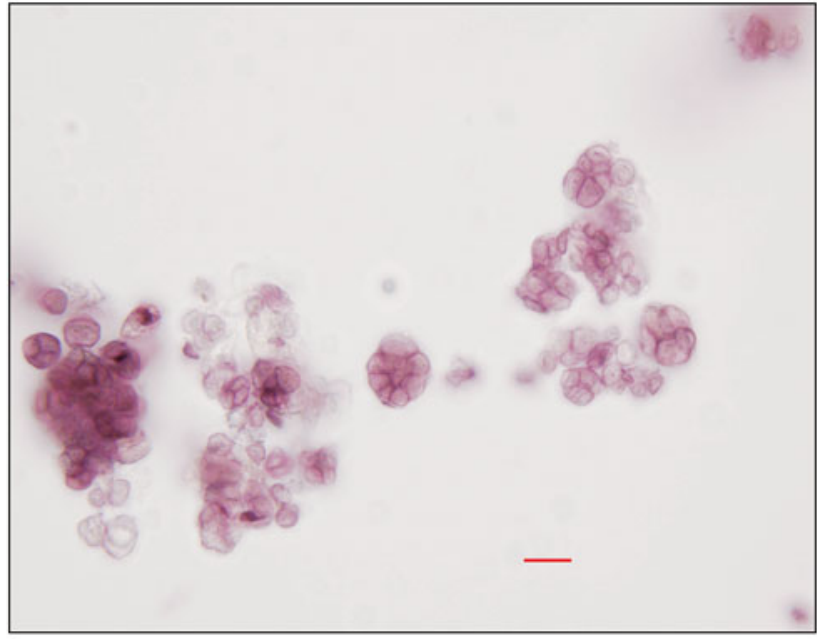

Fig. 7. Aplanochytrid S1961 showing positive reaction for in situ hybridization using biotinylated probes and strepatividinconjugated peroxidase. Scale bar $=10 \mu \mathrm{m}$

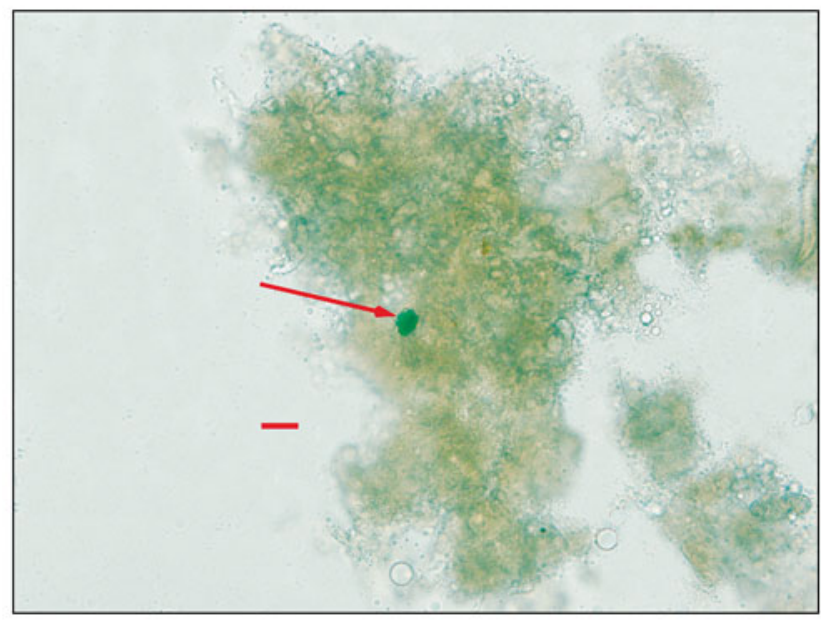

Fig. 8. In situ hybridization of aggregates from the equatorial Indian Ocean using biotinylated internal transcribed spacer (ITS)-probes developed against the aplanochytrid S1961 and S2124 and streptavidin-alkaline phosphatase conjugate. Scale bar $=10 \mu \mathrm{m}$

were detected in the hind gut of several of the zooplankton specimens towards the end of $4 \mathrm{~h}$ of feeding (Fig. 9). No aplanochytrid cells were detected in the specimens after $6 \mathrm{~h}$ and more of feeding. However, blue colouration owing to reaction to alkaline phosphatase used in the ISH was noticed in different parts of the body of zooplankton, such as the appendages and metasome (Fig. 10). The colour intensity decreased after $15 \mathrm{~h}$ of feeding. No reaction to ISH and, therefore, no development of blue colour that is characteristic of the alkaline phosphatase-BCIP/NBT test was detected in the tissue of the control zooplankton specimens that were not fed with aplanochytrids.
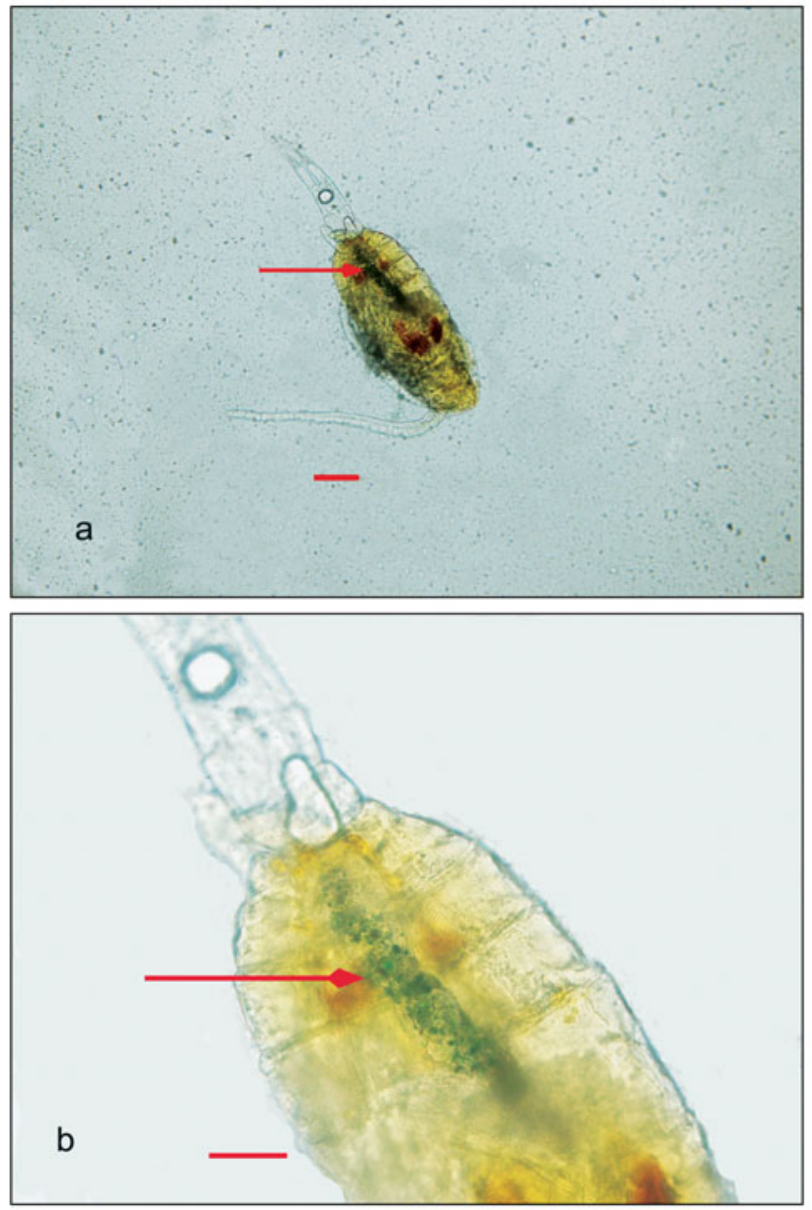

Fig. 9. A specimen of zooplankton fed with the aplanochytrid S1961 showing a positive reaction in the gut for in situ hybridization using probes for the aplanochytrid isolate and with Streptavidin-alkaline phosphatase conjugate. (b) High power photograph of (a). Scale bars = (a) $100 \mu \mathrm{m}$, (b) $50 \mu \mathrm{m}$

\section{Natural zooplankton population from the equatorial Indian Ocean}

Specimens from both the cruises (October 2004 and September 2006) showed positive reactions towards probes developed for both the isolates S1961 and S2124 using the streptavidin-ALP conjugate (Tables 4 \& 5). The use of the S61F1 probe yielded positive reactions from 1.4 to $27.6 \%$ of zooplankton specimens sampled during October 2004 cruise, while the use of the $138 \mathrm{~F} 1$ probe yielded 0 to $34.9 \%$ positive reactions. ISH-positive specimens of zooplankton were found in all the depths at all 9 stations sampled during this cruise. In contrast, only 2 of the 6 samples collected from the 3 stations were positive to the S61F1 probe and only 3 of the 6 samples to the 138F1 probe during the September 2006 cruise. Up 


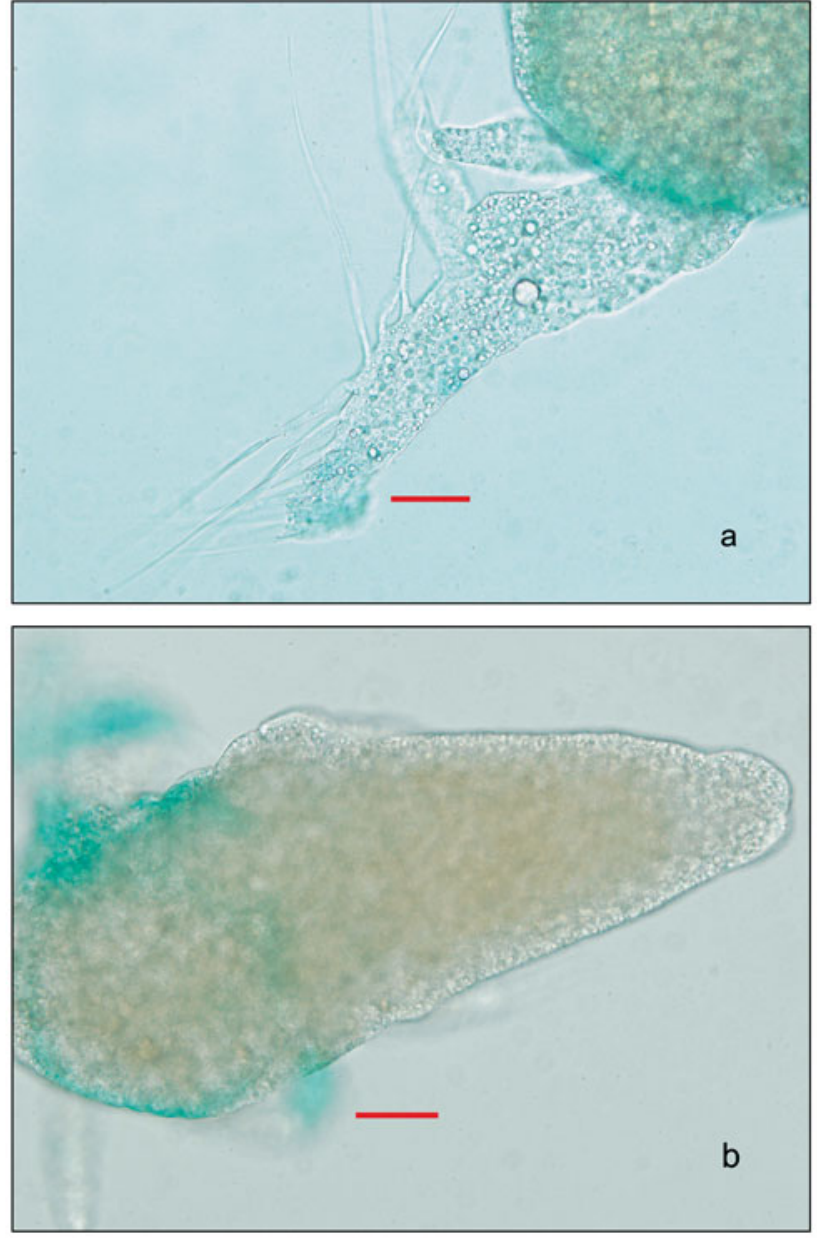

Fig. 10. Blue reaction to the alkaline phosphatase 5-bromo-4chloro-3-indolyl phosphate/nitro blue tetrazolium (BCIP/ NBT) in (a) the appendage and (b) metasome of the zooplankton body, following in situ hybridization using probes for the aplanochytrid S1961. Scale bars $=50 \mu \mathrm{m}$

Table 4. Response of individual zooplankton specimens collected during October 2004 from the equatorial Indian Ocean to in situ hybridization (ISH) using probes designed against 2 isolates of Aplanochytrium kerguelensis. Results in bold signify high positive response amongst the 2 probes at any particular location

\begin{tabular}{|c|c|c|c|c|c|c|c|}
\hline \multirow[t]{2}{*}{ Station } & \multirow{2}{*}{$\begin{array}{l}\text { Depth } \\
\text { (m) }\end{array}$} & \multicolumn{3}{|c|}{ S61F1 probe } & \multicolumn{3}{|c|}{ 138F1 probe } \\
\hline & & $\begin{array}{c}\text { Total spe- } \\
\text { cimens }\end{array}$ & $\begin{array}{c}\text { Total } \\
\text { positive }\end{array}$ & $\begin{array}{c}\% \\
\text { positive }\end{array}$ & $\begin{array}{c}\text { Total spe- } \\
\text { cimens }\end{array}$ & $\begin{array}{c}\text { Total } \\
\text { positive }\end{array}$ & $\begin{array}{c}\% \\
\text { positive }\end{array}$ \\
\hline $1^{\circ} \mathrm{N}, 80.5^{\circ} \mathrm{E}$ & $30-200$ & 63 & 3 & 4.8 & 43 & 15 & 34.9 \\
\hline $0^{\circ} \mathrm{Eq}, 80.5^{\circ} \mathrm{E}$ & $38-200$ & 63 & 4 & 6.3 & 135 & 4 & 9.3 \\
\hline $0^{\circ} \mathrm{Eq}, 80.5^{\circ} \mathrm{E}$ & $200-500$ & 59 & 5 & 8.5 & 54 & 6 & 14.0 \\
\hline $0^{\circ} \mathrm{Eq}, 83^{\circ} \mathrm{E}$ & $500-1000$ & 40 & 3 & 7.5 & 64 & 0 & 0.0 \\
\hline $0^{\circ} \mathrm{Eq}, 83^{\circ} \mathrm{E}$ & $300-500$ & 22 & 3 & 13.6 & 29 & 5 & 11.6 \\
\hline $0^{\circ} \mathrm{Eq}, 83^{\circ} \mathrm{E}$ & $0-30$ & 58 & 16 & 27.6 & 77 & 7 & 16.3 \\
\hline $1^{\circ} \mathrm{S}, 80.5^{\circ} \mathrm{E}$ & $500-1000$ & 73 & 1 & 1.4 & 68 & 0 & 0.0 \\
\hline $1^{\circ} \mathrm{S}, 80.5^{\circ} \mathrm{E}$ & $200-500$ & 61 & 3 & 4.9 & 52 & 7 & 16.3 \\
\hline $0^{\circ} \mathrm{Eq}, 77^{\circ} \mathrm{E}$ & $60-200$ & 50 & 2 & 4.0 & 56 & 2 & 4.7 \\
\hline
\end{tabular}

to $12.5 \%$ of the zooplankton specimens were positive to the S61F1 probe during the cruise, while 0 to $9.3 \%$ were positive to the $138 \mathrm{~F} 1$ probe at the other depths (Table 5). No distinct differential response to the 2 probes was noticed either between the cruises or the depths. Although positive reactions were seen to hybridization, no distinct aplanochytrid cells were detected in the specimens. The reaction was often generalized and found in various parts of the zooplankton.

While generally only a few copepods were positive for hybridization with the 2 probes using streptavidinALP, all the chaetognath specimens were positive (Fig. 11). Several globose, scattered cells that reacted positively to ISH were observed within the body of the chaetognaths. Positive reactions were mostly concentrated surrounding the gut and also inside the mouth parts. In one instance, an aggregate-like structure in the vicinity of the mouth part of the chaetognath reacted positively to ISH (Fig. 11a).

In situ PCR of chaetognath specimens revealed fewer ISH-positive cells within the tissue of chaetognaths compared to the procedure where only electroporation was used prior to ISH. However, the application of in situ PCR resulted in cells which stained much brighter with streptavidin-ALP (Fig. 12). Cells that reacted positively to in situ PCR-ISH were mostly ellipsoidal to irregular in shape. Such aplanochytridpositive cells were present lining the gut.

\section{ISH of chaetognath specimen using streptavidin- peroxidase conjugate}

In order to eliminate the possibility of false positive reactions and as a step towards confirmation of probe efficiency, samples were subjected to ISH using streptavidinperoxidase conjugate. BSA in the presence of Tween20 was more efficient than skimmed milk powder as a blocking agent, only 10 out of the total 32 specimens of chaetognaths $(31.3 \%)$ showing a diffuse and generalized positive reaction to ISH unlike that seen with the streptavidin-ALP conjugate $(100 \%$ positive staining). Aplanochytrid cells that stained positively to DAB hydrochloride hydrate were observed in several parts of chaetognath specimens such as in the head region, tail region and surrounding the gut (Fig. 13). 
Table 5. Response of individual zooplankton specimens collected during September 2006 from the equatorial Indian Ocean to in situ hybridization (ISH) using probes designed against 2 isolates of Aplanochytrium kerguelensis. Results in bold signify high positive response amongst the 2 probes at any particular location

\begin{tabular}{|c|c|c|c|c|c|c|c|}
\hline \multirow[t]{2}{*}{ Station } & \multirow{2}{*}{$\begin{array}{c}\text { Depth } \\
\text { (m) }\end{array}$} & \multicolumn{3}{|c|}{$-\mathrm{S} 61 \mathrm{~F} 1$ probe -} & \multicolumn{3}{|c|}{ 138F1 probe -} \\
\hline & & $\begin{array}{c}\text { Total spe- } \\
\text { cimens }\end{array}$ & $\begin{array}{c}\text { Total } \\
\text { positive }\end{array}$ & $\begin{array}{c}\% \\
\text { positive }\end{array}$ & $\begin{array}{c}\text { Total spe- } \\
\text { cimens }\end{array}$ & $\begin{array}{c}\text { Total } \\
\text { positive }\end{array}$ & $\begin{array}{c}\% \\
\text { positive }\end{array}$ \\
\hline $0^{\circ} \mathrm{Eq}, 77^{\circ} \mathrm{E}$ & $200-500$ & 17 & 0 & 0.0 & 23 & 3 & 7.0 \\
\hline $0^{\circ} \mathrm{Eq}, 77^{\circ} \mathrm{E}$ & $0-200$ & 17 & 0 & 0.0 & 31 & 1 & 2.3 \\
\hline $0^{\circ} \mathrm{Eq}, 83^{\circ} \mathrm{E}$ & $200-500$ & 21 & 0 & 0.0 & 36 & 0 & 0.0 \\
\hline $0^{\circ} \mathrm{Eq}, 83^{\circ} \mathrm{E}$ & $0-200$ & 9 & 1 & 11.1 & 9 & 0 & 0.0 \\
\hline $0^{\circ} \mathrm{Eq}, 93^{\circ} \mathrm{E}$ & $200-500$ & 7 & 0 & 0.0 & 5 & 0 & 0.0 \\
\hline $0^{\circ} \mathrm{Eq}, 93^{\circ} \mathrm{E}$ & $0-200$ & 24 & 3 & 12.5 & 24 & 4 & 9.3 \\
\hline
\end{tabular}

kins) Leander and Porter (Damare \& Raghukumar 2006). SSU rDNA sequences of 8 of these isolates confirmed this identification. Thus, phylogenetic trees showed that these 8 isolates were closest to A. yorkensis of the 'A. yorkensis complex' within the aplanochytrids, the other cluster being the 'A. minuta complex' (Leander et al. 2004). All isolates, therefore, corresponded to aplanochytrids, one of the 3 lineages of the Labyrinthulomycetes (Leander \& Porter 2001). None belonged to thraus-

\section{DISCUSSION}

All 14 isolates cultured from zooplankton of the Indian Ocean had earlier been identified, on the basis of their life cycle and other morphological characteristics, as belonging to Aplanochytrium yorkensis (Per- tochytrids or labyrinthulids. The NJ and ME trees were fundamentally consistent with the trees reported by Honda et al. (1999) wherein labyrinthulids grouped with aplanochytrids, distinctly separated from thraustochytrids. A. yorkensis is now considered synonymous to A. kerguelensis Bahnweg \& Sparrow (1972) and is,
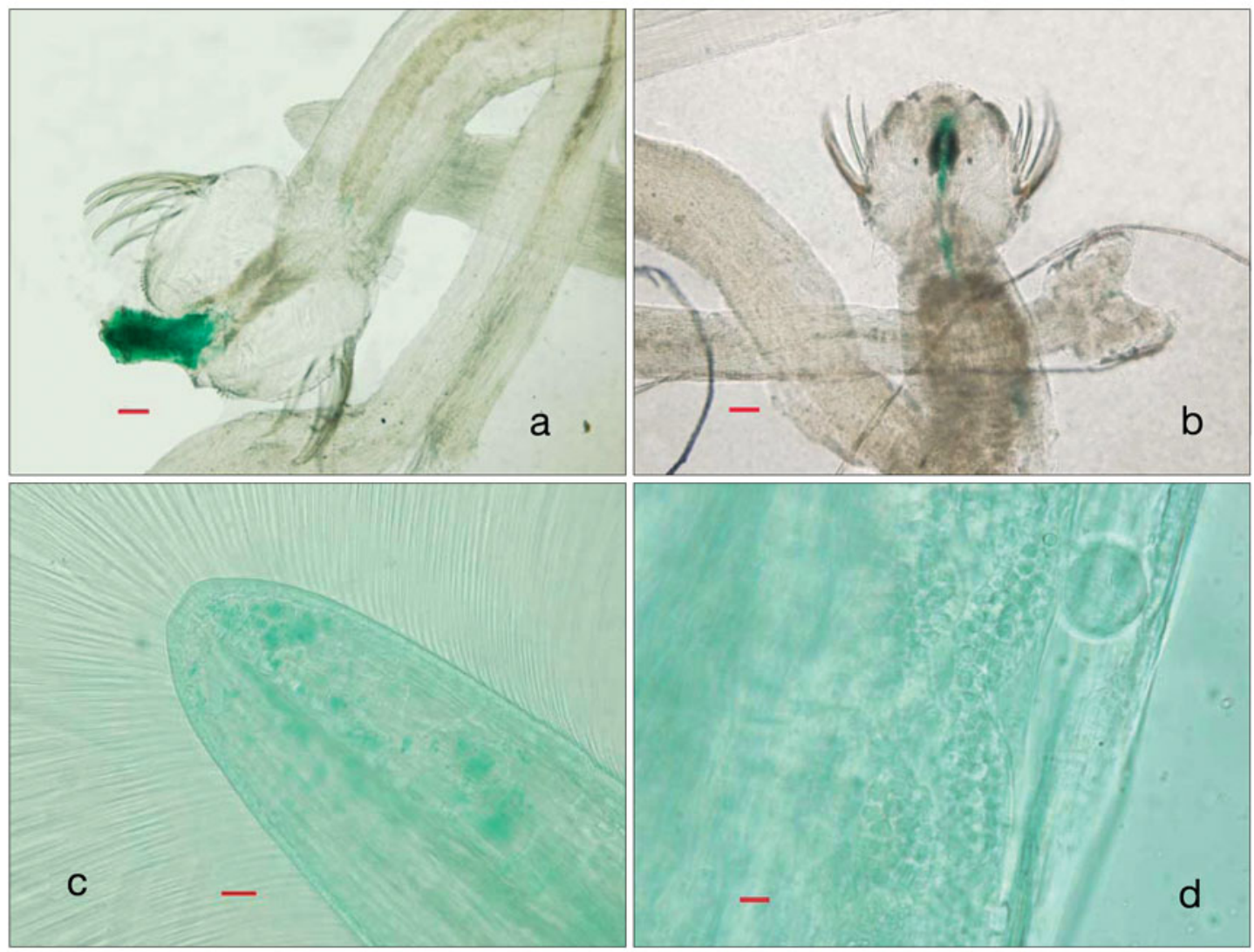

Fig. 11. In situ hybridization of chaetognaths from the equatorial Indian Ocean using biotinylated internal transcribed spacer (ITS)-based probes developed against the aplanochytrid S1961 and S2124. (a) Aggregate-like structure in the vicinity of the mouth part of the chaetognath reacted positively to in situ hybridization; (b) contents inside mouth parts of a specimen showing positive reaction; (c) several positively stained cells seen scattered within the chaetognath body; and (d) surrounding the gut. 


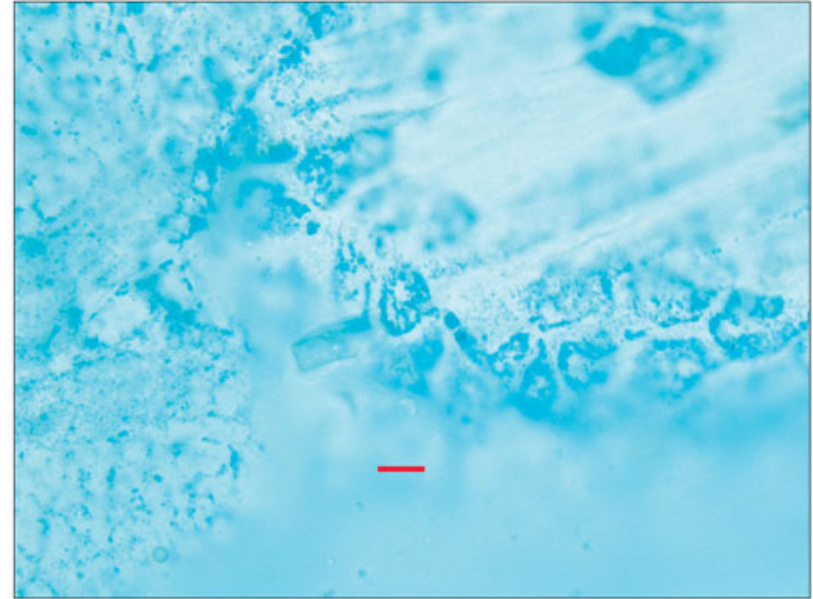

Fig. 12. In situ hybridization of chaetognaths from the equatorial Indian Ocean following in situ PCR, using biotinylated internal transcribed spacer (ITS)-probes developed against the aplanochytrid S2124. Scale bar $=10 \mu \mathrm{m}$ therefore, referred to by that name in the rest of the discussion. Only 14 isolates that survived repeated subculturing of the total 171 isolates from zooplankton had been studied earlier for their morphology and life cycle (Damare \& Raghukumar 2006) and 8 of these that survived further subculturing were identified as that species based on 18S rDNA sequences. Such a small selection from the total may be suspected to have resulted in a bias. However, these were isolates from random depths and stations. Further, the colony morphologies of all 171 isolates corresponded to those of typical aplanochytrids described by Leander et al. (2004) and Damare \& Raghukumar (2006). A. kerguelensis was originally reported from sub-Antarctic waters while $A$. yorkensis was described from oyster mantle, water samples, sediment and detritus from York river in Virginia (Bahnweg \& Sparrow 1972, Perkins 1973). Thus, A. kerguelensis appeared to be the dominant species associated with the equatorial Indian Ocean zooplankton.
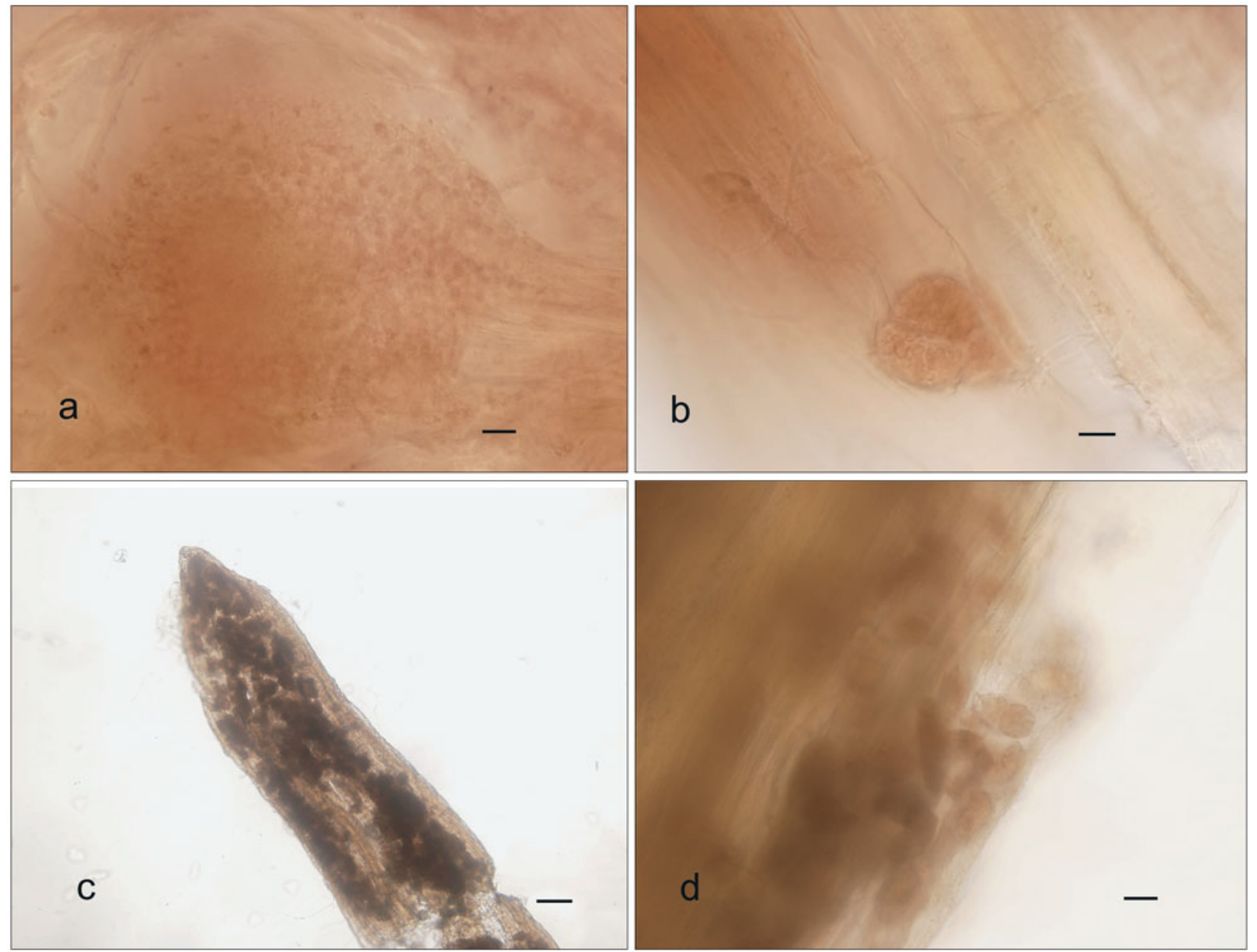

Fig. 13. In situ hybridization of chaetognaths from the equatorial Indian Ocean using biotinylated internal transcribed spacer (ITS)-based probes developed against the aplanochytrid S1961 and S2124 and streptavidin-peroxidase conjugate. Positively stained cells are seen in the (a) head region, $(\mathrm{b}, \mathrm{c})$ tail region, and $(\mathrm{d})$ region surrounding gut but towards periphery. Scale bars $=(\mathrm{a}, \mathrm{b}, \mathrm{d}) 10 \mu \mathrm{m},(\mathrm{c}) 100 \mu \mathrm{m}$ 
We believe that the predominance of the single species Aplanochytrium kerguelensis in the zooplankton of the equatorial Indian Ocean waters is significant for the following reasons: (1) It is likely that aplanochytrids predominate in oceanic waters, compared to thraustochytrids and labyrinthulids. Raghukumar (1985) reported Labyrinthuloides yorkensis (A. kerguelensis) as the only species isolated from water samples of the Arabian Sea. (2) All isolations in the present study were made from zooplankton. Aplanochytrids may have a definite association with zooplankton, compared to thraustochytrids. Zooplankton-associated A. kerguelensis from the equatorial Indian Ocean might represent a genetically distinct population of the species. Thus, 7 of the 8 isolates clustered apart from A. yorkensis, although this was the closest species in the phylogenetic trees. (3) Although standard media for thraustochytrids and aplanochytrids were used to plate zooplankton, it is possible that only A. kerguelensis grew out of these and that oceanic thraustochytrids were not amenable to cultivation using these media. Indeed, culturable numbers of thraustochytrids in natural water samples appear to be far lower than actual numbers. Raghukumar et al. (2001) observed that while up to $1313 \times 10^{3}$ cells of thraustochytrids were present per litre seawater of the Arabian Sea, culture methods yielded only $10.5 \times 10^{3}$ cells $\mathrm{l}^{-1}$, which is a mere $0.08 \%$ of the total numbers. It is well known for bacteria that culturable numbers are far less than the actual numbers, a phenomenon termed 'plate count anomaly' (Staley \& Konopka 1985).

In order to further understand the association of aplanochytrids with zooplankton, ITS-based probes were successfully developed and tested against the protists in natural samples. There have been few similar, earlier attempts. Lyons et al. (2005) generated 2 18S rRNA targeting probes against the hard clam Mercenaria mercenaria parasite 'quahog parasite unknown' or QPX. They used these probes to detect the presence of the parasite in marine aggregates. Takao et al. (2007) have also designed an 18S rRNA targeted probe against thraustochytrids, especially Aurantiochytrium, formerly Schizochytrium. Though they have optimized the fluorescence in situ hybridization (FISH) protocol using this probe, they have not used it for detection in natural samples. Molecular probes can be designed using fluorescent labels such as FITC and rhodamine or biotinylated probes against streptavidinconjugated enzymes such as ALP or horseradish peroxidase (HRP). FISH probes were avoided in this study because zooplankton, on which the probes were intended to be used, have an autofluorescent chitinous exoskeleton that could cause severe interference in detecting the required organism. Therefore, it was decided to use a bright-field microscopy-based bio- tinylated probe, which can react with chromogenic substrate against enzymes to give a coloured reaction. Two streptavidin-conjugated enzymes, namely ALP and peroxidase were used. Both probes tested positive against cultured cells, as well as cells in the aggregates collected from natural water samples.

There are 2 possible ways by which aplanochytrids can occur in association with zooplankton. They may occur as passive inhabitants of the guts of the animals that had fed upon their cells present in the water column. Alternatively, they may occur as a regular symbiotic component in the bodies of the zooplankton. ISH on coastal zooplankton fed with aplanochytrid cells clearly showed the presence of the protistan cells in the guts of the animals. None of the control specimens (i.e. those not fed with the aplanochytrids) were positive. Many copepods showed a blue colouration in their hind guts $4 \mathrm{~h}$ after the cells of the aplanochytrid were added (Fig. 9), thus confirming that the cells were eaten and had passed into the hind gut and that the probes were effective. ISH carried out on chaetognaths from the equatorial Indian Ocean often yielded positive reaction in the foregut part of the organism, suggesting the presence of the aplanochytrids in that region, probably through feeding (Figs. $11 \& 12$ ). The importance of Labyrinthulomycetes (thraustochytrids) in the marine food web, as sources of the omega-3 polyunsaturated fatty acid (PUFA) 'docosahexaenoic acid' (DHA) to zooplankton, has been stressed by many (Fell \& Newell 1998, Kimura et al. 1999, Raghukumar 2002). Although there have been several reports of zooplankton feeding on Labyrinthulomycetes in the laboratory as well as in aquaculture (Brown 2002, Alonzo et al. 2005, Bergé \& Barnathan 2005), there are few reports of actual feeding of zooplankton on these protists in nature. The present study provides strong evidence towards this. There are no detailed reports of PUFAs in aplanochytrids (Raghukumar 2008). If these too are rich in DHA, they would then provide an important source of PUFA to zooplankton.

The possibility that aplanochytrids might live within the body parts of these zooplankton, probably in a mutualistic association, is supported by the observation of clusters of globose cells located within different parts of the body of many chaetognaths, using both the streptavidin-alkaline phosphatase as well as streptavidin-HRP conjugates. In situ PCR on chaetognaths followed by ISH using streptavidin-alkaline phosphatase provided better evidence of the presence of aplanochytrids within the animals. Distinct, angular to amoeboid cells within the tissues of the chaetognaths (Fig. 12), typical of Aplanochytrium yorkensis on a nutrient-agar medium, were observed. This was also seen during ISH using streptavidin-peroxidase, where clumps of cells 
were noticed in the tail region of a few specimens (Fig. 13). Rinkevich \& Rabinowitz (1993) have suggested the occurrence of thraustochytrid cells circulating in the circulatory system of the tunicate Botryllus schlosseri and have found them in various body parts of tunicates, corals, and sponges. These protists were reported as major contaminants in cell lines of these animals (Rinkevich \& Rabinowitz 1997, Rinkevich 1999). However, the detection of aplanochytrids only in a few of the chaetognath specimens casts doubt on a mutualistic association. The possibility of cells growing below the chitinous exoskeletenous moult of the specimens (Fig. 13) cannot be ruled out either.

Although the above observations were highly suggestive of the presence of Aplanochytrium kerguelensis in chaetognaths, they were confounded by the possibility of false positives. Care was taken to inhibit endogenous ALP activity by pre-treatment with DTT, a strong reducing agent. In addition, the specimens had been fixed in formalin, which destroys endogenous alkaline phosphatase activity (Bussolati \& Leonardo 2008). Despite these precautions, the streptavidinalkaline phosphatase conjugate appeared to yield false positives wherein the colour reaction appeared in a diffused manner in many parts of the body of the zooplankton (Fig. 10). This could have resulted from aplanochytrids that were attached to the exterior of various body parts. The diffused colouring and the absence of distinct cells of the aplanochytrid might have also resulted from the destruction of the aplanochytrid cells during processing. However, it is also likely that the reaction was due to the alkaline phosphatase present in the body tissues of zooplankton. Adults as well as juvenile copepods and branchipods are known to produce alkaline phosphatase often associated with cell surfaces (Cembella et al. 1982, Lespilette et al. 2007). Zooplankton secrete this enzyme in the environment (Jamet \& Boge 1998, Gambin et al. 1999, Boge et al. 2006). In view of the above, we also used streptavidin-peroxidase conjugate for ISH. This resulted in much less generalized and diffuse staining of the chaetognaths. Among all the mesozooplankton, chaetognaths were more positive to ISH with alkaline phosphatase as compared to copepods. ISH using streptavidin-peroxidase conjugate on chaetognaths also showed a positive reaction but to a lesser extent than that seen with alkaline phosphatase system.

The 8 species of zooplankton-associated aplanochytrids appeared to be comprised of 2 seasonally differing populations. The SSU ribosomal sequences showed that cultures obtained during SK212, S2122, S2124, S2125, S2128 and S2129 clustered distinctly apart from the isolates S1961 and S19610, isolated during SK196 (Fig. 2). The ITS probes developed for the isolate S2124 was positive for all the others isolated during the same period, namely S2122, S2125, S2128 and S2129 (Fig. 4). Likewise, the probe developed for S1961 was positive for all cultures isolated during SK196 (Fig. 3). However, these observations need to be confirmed by future studies since they were inconsistent with the ISH studies, where specimens of copepods, as well as chaetognaths collected from any one cruise, were positive to both probes.

The present study demonstrates the predominant occurrence of the aplanochytrid Aplanochytrium kerguelensis in association with mesozooplankton of the equatorial Indian Ocean. It might be expected that if such an association occurred, the percentage frequency of isolation of aplanochytrids would have been higher than the observed $8 \%$ of specimens yielding colonies of aplanochytrids. However, such an association might be related to the zooplankton taxon. No attempts were made to separate distinct zooplankton taxa prior to plating on culture media. ISH studies suggested a strong relation between aplanochytrids and chaetognaths. Further studies using electron microscopy and other molecular probes will throw light on possible mutualistic relationships of aplanochytrids with chaetognaths and the role of aplanochytrids in the diet of oceanic mesozooplankton.

Acknowledgements. We acknowledge a grant to V.D. from the Ministry of Ocean Development under the manpower development programme No. DOD/12-MMDP/7/01(P-3). We are thankful to the Director, NIO for providing all facilities for the work and to Dr. V. S. N. Murty (Chief Scientist, Cruises SK196 \& SK228) and Dr. Suryanarayana (Chief Scientist, Cruise SK212) for permission to participate in the cruises. This is NIO's Contribution Number 4655.

\section{LITERATURE CITED}

Alonzo F, Virtue P, Nicol S, Nichols P (2005) Lipids as trophic markers in Antarctic krill. II. Lipid composition of the body and digestive gland of Euphausia superba in controlled conditions. Mar Ecol Prog Ser 296:65-79

Bahnweg G, Sparrow FK (1972) Aplanochytrium kerguelensis gen. nov. spec. nov., a new phycomycete from subantarctic marine waters. Arch Mikrobiol 81:45-49

Bergé JP, Barnathan G (2005) Fatty acids from lipids of marine organisms: molecular biodiversity, roles as biomarkers, biologically active compounds, and economical aspects. Adv Biochem Engin Biotechnol 96:49-125

Biegala IC, Not F, Vaulot D, Simon N (2003) Quantitative assessment of picoeukaryotes in the natural environment by using taxon-specific oligonucleotide probes in association with tyramide signal amplification-fluorescence in situ hybridization and flow cytometry. Appl Environ Microbiol 69:5519-5529

> Bimboim HC, Doly J (1979) A rapid alkaline extraction procedure for screening recombinant plasmid DNA. Nucleic Acids Res 7:1513-1524

Boge G, Jean N, Jamet JL (2006) Seasonal changes in phos- 
phatase activities in Toulon Bay (France). Mar Environ Res 61:1-18

Bower SM (1987) Labyrinthuloides haliotidis n.sp. (Protozoa: Labyrinthomorpha), a pathogenic parasite of small juvenile abalone in a British Columbia mariculture facility. Can J Zool 65:1996-2007

Bower SM, McLean N, Whitaker DJ (1989) Mechanism of infection by Labyrinthuloides haliotidis (Protozoa: Labyrinthomorpha), a parasite of abalone (Haliotis kamtschatkana) (Mollusca: Gastropoda). J Invertebr Pathol 53: 401-409

Brown MR (2002) Nutritional value of microalgae for aquculture. In: Cruz-Suárez LE, Ricque-Marie D, Tapia-Salazar M, Gaxiola-Cortés MG, Simoes N (eds) Avances en Nutrición Acuícola VI. Memorias del VI Simposium Internacional de Nutrición Acuícola. 3 al 6 de Septiembre del 2002, Cancún, Universidad Autónoma de Nuevo León, Monterrey, p 281-292

Bussolati G, Leonardo E (2008) Technical pitfalls potentially affecting diagnoses in immunohistochemistry. J Clin Pathol 61:1184-1192

Cembella AD, Antia NJ, Harrison PJ (1982) The utilization of inorganic and organic phosphorus compounds as nutrients by eukaryotic microalgae: a multidisciplinary perspective. Part I. CRC Crit Rev Microbiol 10:317-391

Damare V, Raghukumar S (2006) Morphology and physiology of the marine straminipilan fungi, the aplanochytrids isolated from the equatorial Indian Ocean. Indian J Mar Sci 35:326-340

Damare V, Raghukumar S (2008) Abundance of thraustochytrids and bacteria in the equatorial Indian Ocean, in relation to transparent exopolymeric particles (TEPs). FEMS Microbiol Ecol 65:40-49

Fell JW, Newell SY (1998) Biochemical and molecular methods for the study of marine fungi. In: Cookse KE (ed) Molecular approaches to the study of the ocean Chapman \& Hall Publishers, London, p 259-283

Frank U, Rabinowitz C, Rinkevich B (1994) In vitro establishment of continuous cell cultures and cell lines from ten colonial cnidarians. MAr Biol 120:491-499

> Gambin F, Bogé G, Jamet D (1999) Alkaline phosphatase in a littoral Mediterranean marine ecosystem: role of the main plankton size classes. Mar Environ Res 47:441-456

Harel M, Ben-Dov E, Rasoulouniriana D, Siboni N and others (2008) A new thraustochytrid strain Fng1, isolated from the surface mucus of the hermatypic coral Fungia granulose. FEMS Microbiol Ecol 64:378-387

Honda D, Yokochi T, Nakahara T, Raghukumar S, Nakagiri A, Schaumann K, Higashihara T (1999) Molecular phylogeny of labyrinthulids and thraustochytrids based on the sequencing of $18 \mathrm{~S}$ ribosomal RNA gene. J Eukaryot Microbiol 46:637-647

Hsu Y, Yang Y, Chen YC, Tung MC, Wu JL, Engelking MH, Leong JC (1995) Development of an in vitro subculture system for the oka organ (lymphoid tissue) of Penaeus monodon. Aquaculture 136:43-55

Jamet D, Boge G (1998) Characterisation of marine zooplankton alkaline phosphatase activity in relation to water quality. Hydrobiologia 373/374:311-316

Kanazawa A, Teshima S, Tokiwa S (1979a) Biosynthesis of fatty acids from palmitic acid in the prawn, Penaues japonicus. Mem Fac Fish Kagoshima Univ 28:17-20

Kanazawa A, Teshima S, Ono K (1979b) Relationship between essential fatty acid requirements of aquatic animals and the capacity for bioconversion of linolenic acid to highly unsaturated fatty acids. Comp Biochem Physiol 63B:295-298
Kimura H, Fukuba T, Naganuma T (1999) Biomass of thraustochytrid protoctists in coastal water. Mar Ecol Prog Ser 189:27-33

> La Cono V, Urzì C (2003) Fluorescent in situ hybridization applied on samples taken with adhesive tape strips. J Microbiol Methods 55:65-71

$>$ Leander CA, Porter D (2001) The Labyrinthulomycota is comprised of three distinct lineages. Mycologia 93:459-464

> Leander CL, Porter D, Leander BS (2004) Comparative morphology and molecular phylogeny of aplanochytrids (Labyrinthulomycota). Eur J Protistol 40:317-328

Lespilette M, Bogé G, Richard S, Jamet JL (2007) Origin and characteristics of the zooplankton phosphatase activity in a coastal ecosystem of the Mediterranean sea (Toulon Bay). Mar Environ Res 63:445-456

> Lubzens E, Marko A, Tietz A (1985) De novo synthesis of fatty acids in the rotifer, Brachionus plicatilis. Aquaculture 47: $27-37$

Lyons MM, Ward JE, Smolowitz R, Uhlinger KR, Gast RJ (2005) Lethal marine snow: pathogen of bivalve mollusc concealed in marine aggregates. Limnol Oceanogr 50: 1983-1988

> Moter A, Göbel UB (2000) Fluorescence in situ hybridization (FISH) for direct visualization of microorganisms. J Microbiol Methods 41:85-112

Nichols PD, Nichols CAM (2008) Microbial signature lipid profiling and exopolysaccharides: experiences initiated with Professor David C White and transported to Tasmania, Australia. J Microbiol Methods 74:33-46

Perkins FO (1973) A new species of marine labyrinthulid Labyrinthuloides yorkensis gen. nov. spec. nov. - cytology and fine structure. Arch Mikrobiol 90:1-17

Porter D (1990) Phylum Labyrinthulomycota. In: Margulis L, Corliss JO, Melkonian M, Chapman DJ (eds) Handbook of Protoctista. Jones and Bartlett, Boston, p 388-398

Porter D, Lingle WL (1992) Endolithic thraustochytrid marine fungi from planted shell fragments. Mycologia 84:289-299

Raghukumar S (1985) Enumeration of thraustochytrids (heterotrophic microorganisms) from the Arabian Sea. Mahasagar Bull Natl Inst Oceanogr 18:457-465

Raghukumar S (1988) Detection of the thraustochytrid protist Ulkenia visurgensis in a hydroid, using immunofluorescence. Mar Biol 97:253-258

Raghukumar S (2002) Ecology of the marine protists, the Labyrinthulomycetes (Thraustochytrids and Labyrinthulids). Eur J Protistol 38:127-145

> Raghukumar S (2008) Thraustochytrid marine protists: production of PUFAs and other emerging technologies. Mar Biotechnol 10:631-640

Raghukumar S, Raghukumar C (1999) Thraustochytrid fungoid protists in faecal pellets of the tunicate Pegea confoederata, their tolerance to deep-sea conditions and implication in degradation processes. Mar Ecol Prog Ser 190:133-140

Raghukumar S, Schaumann K (1993) An epifluorescence microscopy method for direct detection and enumeration of the fungi-like marine protists, the thraustochytrids. Limnol Oceanogr 38:182-187

> Raghukumar S, Ramaiah N, Raghukumar C (2001) Dynamics of thraustochytrid protists in the water column of the Arabian Sea. Aquat Microb Ecol 24:175-186

- Rinkevich B (1999) Cell cultures from marine invertebrates: obstacles, new approaches and recent improvements. J Biotechnol 70:133-153

Rinkevich B, Rabinowitz C (1993) In vitro culture of blood cells from the colonial protochordate Botryllus schlosseri. In Vitro Cell Dev Biol 29:79-85 
Rinkevich B, Rabinowitz C (1997) Initiation of epithelial cell cultures from palleal buds of Botryllus schlosseri, a colonial tunicate. In Vitro Cell Dev Biol Anim 33:422-424

Sambrook J, Fritsch EF, Maniatis T (1989) Molecular cloning: a laboratory manual, 2nd edn. Cold Spring Harbor Laboratory Press, Cold Spring Harbor, NY

Smolina I, Lee C, Frank-Kamenetskii M (2007) Detection of low-copy-number genomic DNA sequences in individual bacterial cells by using peptide nucleic acid-assisted rolling-circle amplification and fluorescence in situ hybridization. Appl Environ Microbiol 73:2324-2328

Staley JT, Konopka A (1985) Measurements of in situ activities of nonphotosynthetic microorganisms in aquatic and terrestrial habitats. Annu Rev Microbiol 39:321-346

Editorial responsibility: Hans Heinrich Janssen, Oldendorf/Luhe, Germany
Takao Y, Tomaru Y, Nagasaki K, Sasakura Y, Yokoyama R, Honda D (2007) Fluorescence in situ hybridization using 18S rRNA targeted probe for specific detection of thraustochytrids (Labyrinthulomycetes). Plankton Benthos Res 2:91-97

Thimm T, Tebbe CC (2003) Protocol for rapid fluorescence in situ hybridization of bacteria in cryosections of microarthropods. Appl Environ Microbiol 69:2875-2878

White TJ, Bruns TD, Lee SB, Taylor JW (1990) Analysis of phylogenetic relationships by amplification and direct sequencing of ribosomal DNA genes. In: Innis DH, Sninsky JJ, White TJ (eds) PCR protocols: a guide to methods and applications. Academic Press, New York, p 315-322

Submitted: June 2, 2009; Accepted: August 24, 2009 Proofs received from author(s): January 6, 2010 